\title{
A Study on the Knowledge and Perception Level of Rural Youth Entrepreneurs towards Pisciculture as a Profitable Enterprise in Coastal Odisha
}

\author{
Aditya Kumar Malla*, B. P. Mohapatra, S. P. Sangramsingh and Nagma Halima Saik \\ Department of Extension Education, College of Agriculture, OUAT, Bhubaneswar, India \\ *Corresponding author
}

\section{A B S T R A C T}

Ke y w o r d s
Youth
entrepreneurs,
Weed control,
Predatory, Weed
fish eradication,
Pond environment
monitoring, Health
management,
Aeration and water
exchange

\section{Introduction}

India has a coastline of $7,517 \mathrm{~km}$ and an extensive river and canal system of about $195.210 \mathrm{~km}$, consisting of 14 major rivers, 44 medium rivers and numerous small rivers and streams. Fishing in India is a major industry in its coastal states, employing over 14 million people. Pisciculture contributes around $1 \%$ to India's gross domestic product and over $5 \%$ to the agricultural GDP[1].
Pisciculture contributes around $1 \%$ to India's gross domestic product and over $5 \%$ to the agricultural GDP. The study was conducted in Balikuda, Biridi, Erasama, Jagatsinghpur, Kujanga, Naugaon, Raghunathpur and Tirtol blocks of Jagatsinghpur district. Both purposive and multistage random sampling methods were adopted for selection of the district, gram panchayat, village and respondents. A total of 180 numbers of respondents were selected for the purpose of the investigation. Based on the descriptive statistics, most of the respondentshad medium knowledge about the general pond requirement and manuring and fertilization of the culture pond and harvesting. On the other hand, the youth entrepreneurs in pisciculture had low level of knowledge on predatory and weed fish eradication, stocking of the pisciculture. The youth entrepreneurs in pisciculture had high level of knowledge on harvesting of the pisciculture. Under marketing and storage perception factors 40.55 per cent of the respondents were strongly agreed with preservation of undisposed fishes is difficult. The main aim of pisciculture development program was for making substantial contributions to doubling of food production, improving the welfare of youth entrepreneurs, promoting exports and providing food and livelihood security to its rural youth entrepreneurs. 
the poor fisherman community in terms of income and employment generation. The State ranks 10th in terms of production of fish and produced 4.50 percent of the total fish production in the country during 2014-15. During 2016 -17, Odisha produced 608.10 TMT of fish of which 455.00 TMT came from inland sources and 153.11 TMT from marine sources. During 2018-19, Jagatsinghpur produced 14361 MT of fish came from 3456 ha of fresh water and 2119.33 MT of prawn and 8159.21 MT of shrimp, 260.06 MT of crab and 1457.02 MT of fish came from 1652.39 ha of brackish water.

Youth being enthusiastic, vibrant, innovative and dynamic in nature is the most important section of the population. As per India's Census 2011, Youth (15-24 years) in India constitutes one-fifth $(19.1 \%)$ of India's total population. Entrepreneurship in pisciculture has been connected with a progressive modernization of farming activity and is connected with multifunctional rural development. Small enterprises in rural areas play a major role in the rural economy as they ensure higher economic prosperity to rural people than that of large companies dominating economy with little or no ownership of local people [2].

\section{Materials and Methods}

The study was conducted in Balikuda, Biridi, Erasama, Jagatsinghpur, Kujanga, Naugaon, Raghunathpur and Tirtol blocks of Jagatsinghpur district. Both purposive and multistage random sampling methods were adopted for selection of the district, gram panchayat, village and respondents. A list of youth entrepreneurs in pisciculture of these selected villages was obtained from the Assistant Fisheries Officers and the scientists of $\mathrm{KVK}$, from this list structure random sampling method was followed to select respondents of the study. A total of 180 (hundred eighty) number of respondents were selected for the purpose of the investigation. Ex post facto research design was implemented in the study.

The primary data were collected personally by interviewing the selected respondents with the help of structural and pre-tested interview schedule which was pretested with 10 per cent samples other than the respondents of the study. The secondary data were collected from various government departments, journals, publications and statistics department. The data were analyzed through computer using frequency, percentage, knowledge index score, score gap, mean and standard deviation.

\section{Results and Discussion}

\section{Knowledge about general pond/water resource requirement}

Pond is the basic resource requirement to undertake pisciculture. The shape, location, period of water retention and depth of silt deposited in the pond influence various management practices as well as fish production. Attempt was made to ascertain the knowledge of pisciculture farmers about pond requirements, which was reflected in Table 1.

The data in the above table revealed that out of the total pisciculture farmers, highest percentage i.e. 66.66 per cent was found in medium knowledge category, whereas 21.12 per cent in high and 12.22 per cent in low knowledge categories. Thus, it can be concluded that the higher $(66.66 \%)$ of the pisciculture farmers had medium level of knowledge of general pond requirement.

It was observed from the table that the pisciculture farmers had good knowledge 
about the location of the pond, shape of the pond and type of pond required for undertaking pisciculture. The gap in knowledge level pertaining to pond shape, location and type of pond was found 16. 42 per cent with knowledge index score 10.03, which indicated that the pisciculture farmers were having good knowledge about general pond requirement. It may be concluded that all of the fishermen under study had better knowledge about general pond requirement for pisciculture. This may be due to frequent change agent contact, exposure to various extension activities and presence of research and extension organization in the locality.

\section{Knowledge about predatory and weed fish eradication}

Eradication of predatory and weed fishes from the culture ponds constitute one of the important pre-stocking management practices. The predatory and weed fishes are undesirable is culture pond as they compete for food and oxygen and also feeds on the fry/fingerlings of the cultivated carp species. Attempt was made to investigate the knowledge of the respondents about predatory and weed fish eradication control from culture pond which was presented in Table 2.

The data in the above table found that out of the total pisciculture farmers, highest percentage i.e. 55 per cent was found in low knowledge category, whereas 25 per cent in high and 20 per cent in medium knowledge categories. Thus, it can be concluded that the higher $(55 \%)$ of the pisciculture farmers had low level of knowledge of predatory and weed fish eradication.

It was revealed from the table that all the pisciculture most of farmers were agreed upon the eradication of predatory and weed fishes from the culture ponds. It was also observed that they had no adequate knowledge about the methods of predatory and weed fish control, particularly use of bleaching powder, which was evident from the gap in knowledge level of 41.25 per cent with knowledge index score 7.05. This result showed that pisciculture farmers need more knowledge in detailed about control of predatory and weed fishes. The study therefore suggested that emphasis on conducting a good number of demonstrations on different aspects of pisciculture involving community approach should be tailor made into the plan of work of the related extension organization, particularly Krishi Vigyan Kendras, FFDAs, ATMA and the State Department of Fisheries.

\section{Knowledge about manuring and fertilization of pond}

Manuring and fertilization of the culture pond is pre-requisite in pisciculture. The productivity of the pond can be enhanced through application of organic manure and lime. Sufficient knowledge about manuring and fertilization helps the growers to sustain the natural fish food organism (plankton) in the pond and the soil and water $\mathrm{pH}$ of the pond which is turn affects the fish production. Attempt was made to assess the knowledge of the respondents about manuring and fertilization, reflected in Table 3.

The data presented in the table 3 showed that out of the total pisciculture farmers, highest percentage i.e. 52.22 per cent was found in medium knowledge category, whereas 28.90 per cent in high and 18.88 per cent in low knowledge categories. Thus, it can be concluded that the higher $(52.22 \%)$ of the pisciculture farmers had medium level of knowledge of manuring and fertilization of pond.

Table 3 observed that about 55 per cent of pisciculture farmers were having better knowledge on application of lime for disinfecting the pond. It was observed that the 
gap in knowledge level about pond manuring and fertilization was 20.83 per cent. The study therefore, indicated that efforts by line department staffs for providing sufficient operational procedures manuring and fertilization particularly application of poultry manure, effect of cow dung and lime in pond environment.

\section{Knowledge about stocking}

Standard pisciculture system recommends six species including indigenous culture and exotic carps. They are catla, rohu, mrigal, silver carp, common carp and grass carp. The fingerlings of Indian major carps (indigenous) and exotic carps are stocked in the pond in particular ratio for their optimum growth and production. Attempts were made to know the knowledge of the respondents about pond stocking, presented in Table 4.

It was observed in the table 4 that out of the total pisciculture farmers, highest percentage i.e. 46.11 per cent was found in low knowledge category, whereas 29.44 per cent in medium and 24.45 per cent in high knowledge categories. Thus, it can be concluded that the higher $(46.11 \%)$ of the pisciculture farmers had low level of knowledge of stocking.

Table 4 revealed that the pisciculture farmers were lacking adequate knowledge about the combination for rearing carp species, the size of fish seed to be stocked along with the density and proportion of stocking although they were aware of the types of indigenous and exotic carp species. The gap of knowledge level was found to be 31.25 per cent regarding stocking which indicated that the pisciculture farmers need more knowledge in detail particularly about stocking proportion, density and size of fish seed to be stocked in pond. It may be concluded that $61.68 \%$ of the fish growers were not aware about rearing indigenous and exotic carps together and they were of orthodox type.

Adequate training and technical guidance with exposure programme for the farmers in regular manner should be encouraged for proper knowledge of stocking to enhance fish production. Supply of quality fish seeds of adequate sized fingerlings should be ensured to the farmers through recognized fish seed growers at right time and at right quantities species-wise.

\section{Knowledge about harvesting}

The total duration of culture period varies from 10-12 months. Harvesting of fishes above $500 \mathrm{gm}$ body weight facilitates the growth of other small fishes in the pond. Harvesting is done by repeated netting or by dewatering the pond. The different species of fish, catla, rohu, mrigal, silver carp, common carp and grass carps attains the average body weight of 1000-1200 gm, $700 \mathrm{gm}, 800 \mathrm{gm}$, $1500 \mathrm{gm}, 1000-1500 \mathrm{gm}$ and 2000-2500 gm, respectively at the end of the year, and about 40-70 qtls. of fishes can be produced from one hectare pond per year. The attempt was made to know the knowledge of fish farmers about harvesting of fishes was presented in Table 5.

It was found from the table 5 that majority $36.12 \%$ of the respondents were having high level of knowledge followed by $33.88 \%$ and $30 \%$ respondents acquiring medium and low level of knowledge respectively on the practices of pisciculture technology. The gap in knowledge level of the respondents about harvesting was found to be 0.91 per cent with knowledge index score 11.95. This may be due to frequent change agent contact, exposure to various extension activities and presence of research and extension organization in the locality. 
Table.1 Knowledge of the respondents general pond Requirement ( $\mathrm{N}=180)$

\begin{tabular}{|c|c|c|c|c|c|c|c|}
\hline \multirow[t]{2}{*}{ Sl. No. } & \multirow[t]{2}{*}{ Statements } & \multicolumn{2}{|c|}{ Agree (3) } & \multicolumn{2}{|c|}{$\begin{array}{l}\text { Partially } \\
\text { agree (2) }\end{array}$} & \multicolumn{2}{|c|}{ Disagree(1) } \\
\hline & & $\mathrm{f}$ & $\mathrm{p}$ & f & $\mathrm{p}$ & $\mathrm{f}$ & $\mathrm{p}$ \\
\hline i. & $\begin{array}{l}\text { Pond should be located in an open } \\
\text { space receiving ample sunlight. }\end{array}$ & 121 & 67.24 & 43 & 23.88 & 16 & 8.88 \\
\hline ii. & $\begin{array}{l}\text { Rectangular shape of pond is ideal } \\
\text { for pisciculture. }\end{array}$ & 102 & 56.66 & 34 & 18.88 & 44 & 24.46 \\
\hline iii. & The pond should be perennial & 109 & 60.55 & 39 & 21.66 & 32 & 17.79 \\
\hline iv. & $\begin{array}{l}\text { Fish growth is retarded due to } \\
\text { excessive silt deposition. }\end{array}$ & 143 & 79.45 & 19 & 10.55 & 18 & 10 \\
\hline & Total score & 1425 & & 270 & & 110 & \\
\hline
\end{tabular}

\begin{tabular}{|c|c|c|}
\hline Sl. No. & Knowledge Index score & Score Gap \\
\hline i. & 10.03 & $16.42 \%$ \\
\hline
\end{tabular}

\begin{tabular}{|c|c|c|c|}
\hline Sl. No. & Categories & f & p \\
\hline 1. & Low & 22 & 12.22 \\
\hline $\mathbf{2 .}$ & Medium & 120 & 66.66 \\
\hline 3. & High & 38 & 21.12 \\
\hline
\end{tabular}

Mean $=2.50 \quad S . D=0.74$

This finding is in the line with the finding of Nagarajaiah (2005).[3]

Table.2 Knowledge of the respondents about Predatory and weed fish Eradication (N=180)

\begin{tabular}{|c|c|c|c|c|c|c|c|}
\hline \multirow[t]{2}{*}{ Sl. No. } & \multirow[t]{2}{*}{ Statements } & \multicolumn{2}{|c|}{ Agree (3) } & \multicolumn{2}{|c|}{$\begin{array}{l}\text { Partially } \\
\text { agree (2) }\end{array}$} & \multicolumn{2}{|c|}{ Disagree(1) } \\
\hline & & $\mathrm{f}$ & $\mathrm{p}$ & f & $\mathrm{p}$ & $\mathrm{f}$ & $\mathrm{p}$ \\
\hline i. & $\begin{array}{l}\text { Predatory and weed fishes needs to } \\
\text { be eradicated from the culture ponds } \\
\text { before stocking. }\end{array}$ & 132 & 73.33 & 28 & 15.55 & 20 & 11.12 \\
\hline ii. & $\begin{array}{l}\text { The pond is generally dried out to } \\
\text { control the predatory and weed } \\
\text { fishes. }\end{array}$ & 86 & 47.77 & 49 & 27.23 & 45 & 25 \\
\hline iii. & $\begin{array}{l}\text { In case of perennial ponds, } \\
\text { Bleaching powder is used for } \\
\text { poisoning and killing the predatory } \\
\text { and weed fishes. }\end{array}$ & 83 & 46.12 & 51 & 28.33 & 46 & 25.55 \\
\hline & Total score & 903 & & 256 & & 111 & \\
\hline
\end{tabular}
i. $\quad$ SI. No.
Knowledge Index score
7.05
Score Gap
$41.25 \%$ 


\begin{tabular}{|c|c|c|c|}
\hline Sl. No. & Categories & f & p \\
\hline $\mathbf{1 .}$ & Low & 99 & 55 \\
\hline $\mathbf{2 .}$ & Medium & 36 & 20 \\
\hline 3. & High & 45 & 25 \\
\hline Mean=2.35 & S.D $=0.79$ & & \\
\hline
\end{tabular}

Table.3 Knowledge of the respondents about manuring and fertilization of pond( $(\mathrm{N}=180)$

\begin{tabular}{|c|c|c|c|c|c|c|c|}
\hline \multirow[t]{2}{*}{ SI. No. } & \multirow[t]{2}{*}{ Statements } & \multicolumn{2}{|c|}{ Agree (3) } & \multicolumn{2}{|c|}{$\begin{array}{l}\text { Partially } \\
\text { agree (2) }\end{array}$} & \multicolumn{2}{|c|}{ Disagree(1) } \\
\hline & & $\mathrm{f}$ & $\mathrm{p}$ & $\mathrm{f}$ & $\mathrm{p}$ & $\mathrm{f}$ & $\mathrm{p}$ \\
\hline i. & $\begin{array}{l}\text { Cow-dung is applied to raise the plankton } \\
\text { population in the pond. }\end{array}$ & 129 & 71.68 & 37 & 20.55 & 14 & 7.77 \\
\hline ii. & Liming is corrects soil and water $\mathrm{pH}$. & 101 & 56.11 & 47 & 26.12 & 32 & 17.77 \\
\hline iii. & Liming helps in disinfecting the pond. & 99 & 55 & 47 & 26.12 & 34 & 18.88 \\
\hline iv. & $\begin{array}{l}\text { Poultry litter used as alternative source of } \\
\text { organic manure. }\end{array}$ & 79 & 43.88 & 43 & 23.88 & 58 & 32.24 \\
\hline & Total score & 1224 & & 348 & & 138 & \\
\hline
\end{tabular}

\begin{tabular}{|c|c|c|}
\hline Sl. No. & Knowledge Index score & Score Gap \\
\hline i. & 9.50 & $20.83 \%$ \\
\hline
\end{tabular}

\begin{tabular}{|c|c|c|c|}
\hline Sl. No. & Categories & f & p \\
\hline $\mathbf{1 .}$ & Low & 34 & 18.88 \\
\hline $\mathbf{2 .}$ & Medium & 94 & 52.22 \\
\hline $\mathbf{3 .}$ & High & 52 & 28.90 \\
\hline Mean $=2.41$ & S. D $=0.70$ & & \\
\hline
\end{tabular}

$$
\text { Mean }=2.41 \quad S . D=0.70
$$

The above result is in line with the finding reported by Sharma (2005).[4]

Table4 Knowledge of the respondents about stocking $(\mathrm{N}=180)$

\begin{tabular}{|c|c|c|c|c|c|c|c|}
\hline \multirow[t]{2}{*}{ Sl. No. } & \multirow[t]{2}{*}{ Statements } & \multicolumn{2}{|c|}{ Agree (3) } & \multicolumn{2}{|c|}{$\begin{array}{l}\text { Partially } \\
\text { agree (2) }\end{array}$} & \multicolumn{2}{|c|}{ Disagree(1) } \\
\hline & & f & $\mathrm{p}$ & f & $\mathrm{p}$ & f & $\mathrm{p}$ \\
\hline i. & $\begin{array}{l}\text { Catla, Rohu, Mrigal are indigenous and } \\
\text { Grasscarp, Silvercarp, Common carp are the } \\
\text { exotic carps. }\end{array}$ & 106 & 58.88 & 45 & 25 & 29 & 16.12 \\
\hline ii. & $\begin{array}{l}\text { Indigenous and exotic carps are reared } \\
\text { together in the pond. }\end{array}$ & 37 & 20.55 & 32 & 17.77 & 111 & 61.68 \\
\hline iii. & $\begin{array}{l}\text { The indigenous and exotic carps are stocked } \\
\text { in a particular proportion and number. }\end{array}$ & 56 & 31.12 & 40 & 22.22 & 84 & 46.66 \\
\hline iv. & $\begin{array}{l}\text { Stocking with fingerlings enhances fish } \\
\text { production. }\end{array}$ & 97 & 53.88 & 57 & 31.66 & 26 & 14.46 \\
\hline & Total score & 888 & & 348 & & 250 & \\
\hline
\end{tabular}

\begin{tabular}{|c|c|c|}
\hline Sl. No. & Knowledge Index score & Score Gap \\
\hline i. & 8.25 & $31.25 \%$ \\
\hline
\end{tabular}




\begin{tabular}{|l|c|c|c|}
\hline Sl. No. & Categories & f & p \\
\hline 1. & Low & 83 & 46.11 \\
\hline 2. & Medium & 53 & 29.44 \\
\hline 3. & High & 44 & 24.45 \\
\hline
\end{tabular}

Mean=2.05 S.D $=0.87$

Table.5 Knowledge of the respondents about harvesting ( $\mathrm{N}=180)$

\begin{tabular}{|c|c|c|c|c|c|c|c|}
\hline \multirow[t]{2}{*}{ Sl. No. } & \multirow[t]{2}{*}{ Statements } & \multicolumn{2}{|c|}{ Agree (3) } & \multicolumn{2}{|c|}{$\begin{array}{l}\text { Partially } \\
\text { agree (2) }\end{array}$} & \multicolumn{2}{|c|}{ Disagree(1) } \\
\hline & & $\mathrm{f}$ & $\mathrm{p}$ & $\mathrm{f}$ & $\mathrm{p}$ & $\mathrm{f}$ & $\mathrm{p}$ \\
\hline i. & $\begin{array}{l}\text { Fishes above } 500 \text { gm. body weight } \\
\text { can be harvested from the pond. }\end{array}$ & 49 & 27.22 & 107 & 59.45 & 24 & 13.33 \\
\hline ii. & $\begin{array}{l}\text { The fishes are reared for a period of } \\
\text { one year only in the pond. }\end{array}$ & 43 & 23.88 & 111 & 61.66 & 26 & 14.46 \\
\hline iii. & $\begin{array}{l}\text { Harvesting can be done by netting } \\
\text { or draining out the pond. }\end{array}$ & 85 & 47.23 & 83 & 46.11 & 12 & 6.66 \\
\hline iv. & $\begin{array}{l}\text { The average body weight of the } \\
\text { fishes } \\
\text { per year. } \\
\text { Catla: } 1000-1200 \mathrm{gm} \\
\text { Rohu: } 700 \mathrm{gm} \\
\text { Mrigal : } 800 \mathrm{gm} \\
\text { Commoncarp: } 1000-1500 \mathrm{gm} \\
\text { Silvercarp : } 1500 \mathrm{gm} \\
\text { Grass carp: } 2000-2500 \mathrm{gm}\end{array}$ & 145 & 80.55 & 21 & 11.66 & 14 & 7.75 \\
\hline v. & $\begin{array}{l}40-70 \text { qtls. of fishes can be } \\
\text { produced /ha/yr }\end{array}$ & 118 & 65.55 & 48 & 26.66 & 14 & 7.79 \\
\hline & Total score & 1320 & & 742 & & 90 & \\
\hline
\end{tabular}

\begin{tabular}{|c|c|c|}
\hline Sl. No. & Knowledge Index score & Score Gap \\
\hline i. & 11.95 & $0.91 \%$ \\
\hline
\end{tabular}

\begin{tabular}{|c|c|c|c|}
\hline Sl. No. & Categories & f & p \\
\hline $\mathbf{1 .}$ & Low & 54 & 30 \\
\hline $\mathbf{2 .}$ & Medium & 61 & 33.88 \\
\hline $\mathbf{3 .}$ & High & 65 & 36.12 \\
\hline
\end{tabular}


Table.6 Perception towards piscicultureof the respondents $(\mathrm{N}=180)$

\begin{tabular}{|c|c|c|c|c|c|c|c|c|c|c|c|}
\hline \multirow[t]{3}{*}{ Sl. No. } & \multirow[t]{3}{*}{ Statements } & \multicolumn{10}{|c|}{ Perception } \\
\hline & & \multicolumn{2}{|r|}{ SA } & \multicolumn{2}{|c|}{ A } & \multicolumn{2}{|c|}{ UD } & \multicolumn{2}{|c|}{ DA } & \multicolumn{2}{|c|}{ SDA } \\
\hline & & $\mathrm{f}$ & $\mathrm{p}$ & $\mathrm{f}$ & $\mathrm{p}$ & f & $\mathrm{p}$ & $\mathrm{f}$ & $\mathrm{p}$ & $\mathrm{f}$ & $\mathrm{p}$ \\
\hline & $\begin{array}{l}\text { Social perception } \\
\text { factors }\end{array}$ & & & & & & & & & & \\
\hline i. & $\begin{array}{l}\text { Only practised by } \\
\text { the traditional } \\
\text { "Kaivartya" } \\
\text { families }\end{array}$ & 3 & 1.66 & 13 & 7.22 & 6 & 3.33 & 39 & 21.66 & 119 & 66.13 \\
\hline ii. & $\begin{array}{l}\text { Malnutrition } \\
\text { problem can be } \\
\text { solved. }\end{array}$ & 29 & 16.11 & 7 & 3.88 & 103 & 57.24 & 28 & 15.55 & 13 & 7.22 \\
\hline iii. & $\begin{array}{l}\text { Family labour can } \\
\text { effectively utilized. }\end{array}$ & 62 & 34.46 & 71 & 39.44 & 24 & 13.33 & 14 & 7.77 & 9 & 5 \\
\hline iv. & $\begin{array}{l}\text { Home and farm } \\
\text { waste can be } \\
\text { effectively utilized. }\end{array}$ & 9 & 5 & 12 & 6.66 & 14 & 7.77 & 94 & 52.24 & 51 & 28.33 \\
\hline \multirow[t]{2}{*}{ v. } & $\begin{array}{l}\text { Chance of outbreak } \\
\text { of fish diseases is } \\
\text { more than } \\
\text { traditional farming. }\end{array}$ & 16 & 8.88 & 21 & 11.66 & 11 & 6.13 & 87 & 48.33 & 45 & 25 \\
\hline & $\begin{array}{l}\text { Economical } \\
\text { perception factors }\end{array}$ & & & & & & & & & & \\
\hline vi. & More profitable & 146 & 81.13 & 17 & 9.44 & 6 & 3.33 & 4 & 2.22 & 7 & 3.88 \\
\hline vii. & $\begin{array}{l}\text { Provide self- } \\
\text { employment and } \\
\text { income generation. }\end{array}$ & 150 & 83.34 & 13 & 7.22 & 9 & 5 & 6 & 3.33 & 2 & 1.11 \\
\hline viii. & $\begin{array}{l}\text { Requires higher } \\
\text { investment. }\end{array}$ & 26 & 14.44 & 101 & 56.13 & 6 & 3.33 & 19 & 10.55 & 28 & 15.55 \\
\hline ix. & $\begin{array}{l}\text { The practice is } \\
\text { labourintensive and } \\
\text { risky. }\end{array}$ & 30 & 16.66 & 15 & 8.33 & 17 & 9.46 & 87 & 48.33 & 31 & 17.22 \\
\hline \multirow[t]{2}{*}{$\mathbf{x}}$. & $\begin{array}{l}\text { Complicated } \\
\text { procedure to avail } \\
\text { loan from banks or } \\
\text { other source. }\end{array}$ & 67 & 37.23 & 49 & 27.22 & 27 & 15 & 18 & 10 & 19 & 10.55 \\
\hline & $\begin{array}{l}\text { Technological } \\
\text { perception factors }\end{array}$ & & & & & & & & & & \\
\hline xi. & $\begin{array}{l}\text { The exotic carps } \\
\text { grow better than } \\
\text { the } \\
\text { Indian major carps. }\end{array}$ & 68 & 37.77 & 79 & 43.88 & 8 & 4.47 & 17 & 9.44 & 8 & 4.44 \\
\hline xii. & $\begin{array}{l}\text { Rearing of Indian } \\
\text { major carps with } \\
\text { exotic carps give } \\
\text { better yield and } \\
\text { return. }\end{array}$ & 99 & 55 & 33 & 18.33 & 13 & 7.22 & 17 & 9.45 & 18 & 10 \\
\hline xiii. & $\begin{array}{l}\text { Less demand for } \\
\text { the exotic carp than } \\
\text { the Indian major } \\
\text { carps in the } \\
\text { locality. }\end{array}$ & 103 & 57.22 & 47 & 26.11 & 6 & 3.33 & 9 & 5 & 15 & 8.34 \\
\hline
\end{tabular}




\begin{tabular}{|c|c|c|c|c|c|c|c|c|c|c|c|}
\hline xiv. & $\begin{array}{l}\text { Technologies are } \\
\text { not easily available. }\end{array}$ & 11 & 6.13 & 17 & 9.44 & 13 & 7.22 & 93 & 51.66 & 46 & 25.55 \\
\hline \multirow[t]{2}{*}{ xv. } & $\begin{array}{l}\text { Inputs and } \\
\text { implements are } \\
\text { easily available. }\end{array}$ & 42 & 23.33 & 56 & 31.13 & 16 & 8.88 & 36 & 20 & 30 & 16.66 \\
\hline & $\begin{array}{l}\text { Marketing and } \\
\text { storage perception } \\
\text { factors }\end{array}$ & & & & & & & & & & \\
\hline xvi. & $\begin{array}{l}\text { No problem in } \\
\text { marketing of fishes. }\end{array}$ & 43 & 23.88 & 67 & 37.22 & 16 & 8.88 & 37 & 20.58 & 17 & 9.44 \\
\hline xvii. & $\begin{array}{l}\text { Preservation of } \\
\text { undisposed fishes } \\
\text { is } \\
\text { difficult. }\end{array}$ & 73 & 40.55 & 71 & 39.46 & 3 & 1.66 & 19 & 10.55 & 14 & 7.77 \\
\hline xviii. & $\begin{array}{l}\text { Transporting of } \\
\text { fishes to distant } \\
\text { market is difficult }\end{array}$ & 59 & 32.77 & 46 & 25.55 & 17 & 9.44 & 37 & 20.56 & 21 & 11.68 \\
\hline \multirow[t]{2}{*}{ xix. } & $\begin{array}{l}\text { Low price for the } \\
\text { fishes in the local } \\
\text { market }\end{array}$ & 62 & 34.44 & 51 & 28.33 & 11 & 6.11 & 33 & 18.33 & 23 & 12.79 \\
\hline & $\begin{array}{l}\text { Perception } \\
\text { towards Extension } \\
\text { activities }\end{array}$ & & & & & & & & & & \\
\hline $\mathbf{x x}$ & $\begin{array}{l}\text { Building and } \\
\text { maintaining } \\
\text { rapports with the } \\
\text { pisciculture youth } \\
\text { entrepreneurs }\end{array}$ & 85 & 47.22 & 66 & 36.68 & 7 & 3.88 & 13 & 7.22 & 9 & 5 \\
\hline xxi. & $\begin{array}{l}\text { Providing the } \\
\text { technical guidance } \\
\text { to the pisciculture } \\
\text { youth entrepreneurs }\end{array}$ & 87 & 48.33 & 63 & 35 & 11 & 6.11 & 11 & 6.11 & 8 & 4.45 \\
\hline xxii. & $\begin{array}{l}\text { Conducting field } \\
\text { day, demonstration, } \\
\text { exhibition etc. }\end{array}$ & 55 & 30.55 & 47 & 26.11 & 17 & 9.46 & 38 & 21.11 & 23 & 12.77 \\
\hline xxiii. & $\begin{array}{l}\text { Lack of mass } \\
\text { media and farm } \\
\text { publications in } \\
\text { local language. }\end{array}$ & 48 & 26.66 & 39 & 21.69 & 14 & 7.77 & 41 & 22.77 & 38 & 21.11 \\
\hline xxiv. & $\begin{array}{l}\text { Solving problems } \\
\text { immediately }\end{array}$ & 47 & 26.13 & 53 & 29.44 & 23 & 12.77 & 21 & 11.66 & 36 & 20 \\
\hline
\end{tabular}

What is your perception towards pisciculture, please give your views about the statements given below

\section{Perception towards pisciculture}

The ability to become aware of pisciculture through the senses called perception. This is the way in which pisciculture technology was understood by the youth entrepreneur. This refers to the set of processes in which youth entrepreneur use to make sense of different stimuli they presented with. They are perceptions are based on how they interpret different sensations about pisciculture. The perceptual process begins with receiving stimuli from the environment and ends with youth entrepreneurs interpretation about pisciculture stimuli. 
The data in Table 6 represents the level of perception of various factors by respondents towards pisciculture as a profitable enterprise. Under social perception factors, the highly perceived factor was utilization of family labour in pisciculture enterprise (34.4 per cent) followed by solving the problem of malnutrition through pisciculture (16.11 per cent). Under economical perception factors majority of respondents strongly agreed that pisciculture can provide self-employment and income generation among the youth in local area (83.34 per cent) followed by respondents who strongly agreed that pisciculture was more profitable enterprise than other enterprise (81.13 per cent). Under technological perception, the respondents strongly agreed to the factor that the less demand for the exotic carp than the Indian major carps in the locality (57.22 per cent) followed by better yield and return in rearing of Indian major carps with exotic carps (55 per cent). Under marketing and storage perception factors, the highly perceived factor by the respondents was difficulty in preservation of undisposed fishes (40.55 per cent) followed by low price for the fishes in the local market (34.44 per cent). Under perception towards extension activities, the respondents strongly agreed with providing technical guidance to the pisciculture youth entrepreneurs by extension officials (48.33 per cent) followed by the factor that extension agents were good enough in building and maintaining rapports with the pisciculture youth entrepreneurs (47.22 per cent).

In conclusion based on the descriptive statistics, most of the respondentshad medium knowledge about the general pond requirement $(66.66 \%)$ and manuring and fertilization $(52.22 \%)$. On the other hand, 55 per cent and 46.11 per cent of the youth entrepreneurs in pisciculture had low level of knowledge on predatory and weed fish eradication and stocking of the pisciculture respectively.36.12per cent of the youth entrepreneurs in pisciculture had high level of knowledge on harvesting of the pisciculture. Under social perception factors out of the total youth entrepreneur in pisciculture, majority $(34.46 \%)$ of the respondents were strongly perceived that family labour can effectively utilized in pisciculture enterprise. Under economical perception factors 83.34 per cent of the respondents were strongly agreed with the factor that pisciculture provides self-employment and income generation among the youth in local area. 57.22 per cent of the youth entrepreneurs in pisciculture were strongly agreed with the technological perception factor that the less demand for the exotic carp than the Indian major carps in the locality. Under marketing and storage perception factors 40.55 per cent of the youth entrepreneurs in pisciculture were strongly agreed with preservation of undisposed fishes is difficult. Under perception towards extension activities 48.33 per cent of the respondents were strongly agreed with the factor that extension personnel providing the technical guidance to the pisciculture youth entrepreneurs.

\section{Acknowledgement}

Token of deep gratitude and warm regards is being rendered to Dr. S.P. Sangramsingh and Dr. B.P. Mohapatra for their persistent endeavour, valuable advice and for always lending a helping hand during the entire course of my study. My appreciation goes to BabasisParija (AFO) and other Assistant Fisheries Officers as well as District Fisheries Officer of Jagatsinghpur District for their cooperation during data collection and generous devotion of their precious time and effort.

\section{References}

Balasubramanium, S. and Kaul, P.N. 
(1985).Adoption of improved practices by traditional fishermen in Kerala.IndJ.Ext.Edn.,21(3\&4): 80-88. Haque,M.A. and Ray, G.L. (1983). Fish farmers' perception of problems in composite fish culture and measures suggested by them for increasing the yield of fish. Ind.J.Ext.Edn., 19 (3\&4): 56-61.

Nagarajaiah. C. S., Biradar. R. S., Gouda. S., Ojha S. N. and Saleem S. S. (2005)
"Influencing the knowledge level of the fish farmers in southern Karnataka" Karnataka J. of Agri. Sci., Vol. 18 No. 2 pp. 415-421.

Sharma Vikram, Dixit V.B. and Laharia S.N. (2005) "Knowledge and Adoption of fish production Technology.Indian $J$. Extn.Edu., Vol. 41. No. 1 \&2, pp. 113116.

\section{How to cite this article:}

Aditya Kumar Malla, B. P. Mohapatra, S. P. Sangramsingh and Nagma Halima Saik. 2021. A Study on the Knowledge and Perception Level of Rural Youth Entrepreneurs towards Pisciculture as a Profitable Enterprise in Coastal Odisha. Int.J.Curr.Microbiol.App.Sci. 10(02): 393-403. doi: https://doi.org/10.20546/ijcmas.2021.1002.046 